\title{
THE USE OF MOLDAVIAN DRAGONHEAD BAGASSE WASTE IN EXTRUDED PRODUCTS
}

\author{
Tomasz ONISZCZUK ${ }^{*}$, Agnieszka WÓJTOWICZ1 ${ }^{1}$, Sławomir KOCIRA ${ }^{2}$, \\ Katarzyna ŻELIZKO ${ }^{1}$, Anna ONISZCZUK ${ }^{3}$, Ahlem DIB ${ }^{4}$ \\ ${ }^{1}$ University of Life Sciences in Lublin, Department of Thermal Technology and Food Process Engineering, \\ POLAND \\ ${ }^{2}$ University of Life Sciences in Lublin, Department of Machinery Exploitation and Management of \\ Production Processes, POLAND \\ ${ }^{3}$ Medical University of Lublin, Department of Inorganic Chemistry, POLAND \\ ${ }^{4}$ Université des Frères Mentouri Constantine, Institut de la Nutrition, de l'Alimentation et des Technologies \\ Agro-Alimentaires, 25000,Constantine, ALGERIA \\ E-mail of corresponding author: tomasz.oniszczuk@up.lublin.pl
}

Keywords: corn, Moldavian dragonhead, waste management, physical properties, texture

\begin{abstract}
Dracocephalum moldavica $\mathrm{L}$. residues after the cold oil pressing were added as supplementation to corn snacks in the amount of 5-30\%. The experiment assessed the effect of addition of the dragonhead bagasse (oilcake) on the selected physical properties and texture of snacks. Directly expanded snacks were made with the extrusion-cooking technique at $14 \%$ of initial moisture of blends. The processing was carried out at $100 \mathrm{rpm}$, at the temperature ranged $115-140^{\circ} \mathrm{C}$ with a 3-mm forming die. The snacks were then tested to evaluate apparent and bulk density and the water absorption and water solubility indices, as well as the cutting force for texture. The increasing amount of dragonhead seed oilcake showed a significant impact on the physical properties of extrudates, lowering bulk density and water absorption, but increasing apparent density, water solubility and the cutting force of the enriched snacks. The application of dragonhead residues as an additive to corn crisps could be an effective way to limiting the oil waste after pressing and increasing the sustainability of waste management. A new range of nutritionally valuable snacks could be also introduced to the market.
\end{abstract}

\section{INTRODUCTION}

The Moldavian dragonhead (Dracocephalum moldavica L., Lamiaceae) is known as an herbal plant with specific properties, such as the presence of phenolic compounds, especially flavonoids (Yang et al. 2014). Primarily, the main raw material for medicinal purposes is the leaves and flowers of Dracocephalum moldavica used as infusion to treat stomach and liver disorders, headaches and congestion, coronary heart disorders and hypertension (Dastmalchi et al. 2007; Yang et al. 2014). There are some latest reports showing the application of dragonhead extracts as a therapeutic agent in many dysfunctions: cardioprotective, antiplatelet, neuroprotective, sedatives and anti-aging (Jiang et al. 2014; Gagoś et al. 2011). Dragonhead seeds are a good source of protein, lipids and fiber (Aprotosoaie et al., 2016; Dziki et al. 2013). Dragonhead seeds are also recognized as useful for the extraction of valuable oil. The seeds contain a high amount of fat (around 30\%), in which $90 \%$ are unsaturated fatty acids, mainly omega-3 fatty acids. The plant has been confirmed as a good source of linolenic acid (59.4\% in seeds after processing to obtain volatile oils) (Domokos et al. 1994). After obtaining oil by cold pressing, there are some residues left containing protein with an unchanged nutritional value, relative to the starting material (Hanczakowski et al. 2009). Taking these positive nutritional features of dragonhead seeds into consideration, the residues of cold oil pressing could be a valuable source of protein and unsaturated fatty acids. One of the 


\section{DOI:}

useful waste management methods is extrusion-cooking. This HTST (high-temperature short-time) method is based on the thermal and mechanical processing of raw materials into food and feed products with unique characteristics. As regards the short-time treatment, extrusion-cooking is one of the most effective treatment methods which only slightly reduce the nutritional value of components. A limited destruction of the nutritional components and biologically active compounds (e.g. antioxidants) coupled with the improvement in starch and protein digestibility are just a few advantages of this process (Oniszczuk et al. 2015; Wójtowicz et al. 2017). These advantages make the extrusion-cooking suitable as a processing method of many food and feed products, e.g. crisps, pasta, breakfast cereals, instant products, flat bread, confectionery, and many others (Bouasla i in., 2016; Kręcisz and Wójtowicz 2017; Wójtowicz et al., 2015). The aim of this study was the application of dragonhead seed waste left after cold oil pressing in snacks and the evaluation of some selected physical properties and texture of snacks extruded with the various amounts of this additive.

\section{MATERIALS AND METHODS}

Corn grits (purchased from Lubella Sp. z o.o. Sp. K., Lublin, Poland) were used as the basic raw material. The Dracocephalum moldavica L. seeds were collected in 2016 and stored in dark conditions until tests. The seeds were pressed with a single screw oil press with the cold method to collect oil samples; the residue as bagasse waste (oilcake) was collected after pressing, stored in a refrigerator and then ground with the laboratory grinder LMN10 (TestChem, Radlin, Poland) to a granulation below $0.8 \mathrm{~mm}$. Ground dragonhead bagasse was added to corn grits in the amount of 5-30\%, mixed and moistened to the final blend moisture of $14 \%$. The extrusion-cooking process was performed with the single screw extruder TS-45 (Metalchem, Gliwice, Poland) at $\mathrm{L} / \mathrm{D}=12: 1$ and with the compression ratio of $3: 1$. The processing temperature ranged $115-140^{\circ} \mathrm{C}$ and the screw speed was $100 \mathrm{rpm}$. The snacks were shaped with a single-opening forming die of $3 \mathrm{~mm}$ in diameter. The obtained samples were dried at $40^{\circ} \mathrm{C}$ for several hours until the final moisture content of $6 \%$. Selected physical properties of snacks were tested as well as texture. Apparent density was determined by substituting sand weight for extrudates volume and dividing it by sand density. Extruding bulk density (BD) was calculated as a mass $(\mathrm{kg})$ of specific sample volume $\left(\mathrm{m}^{3}\right)$ using a measuring cylinder filled gently with snacks (Wójtowicz et al. 2017). The density measurements were reported as an average of five replications. The water absorption index (WAI) and the water solubility index (WSI) were determined by means of centrifugation (Bouasla et al. 2017) for each sample in five replications. The WAI was calculated as the amount of absorbed water $(\mathrm{g})$ per $\mathrm{g}$ of dry sample. The water solubility index (WSI) was determined as solids recovered after the total evaporation of water at $105^{\circ} \mathrm{C}$ of supernatant obtained from the WAI analysis. Texture as cutting force $\left(\mathrm{F}_{\max }\right)$ was tested with a Warner-Bratzler steel blade at the test speed of $500 \mathrm{~mm} \cdot \mathrm{min}^{-1}$ with Zwick BDO- FB0.5TH machine (Zwick GmbH \& Co., Germany) in 10 replications. The obtained results were tested with the F-test and the Kruskal-Wallis one-way analysis of variance with the amount of additive as a variable factor was analyzed with Statistica (version 10.0, USA).

\section{RESULTS AND DISCUSSION}

Extrusion-cooking of corn snacks supplemented with dragonhead bagasse in the amount of $5-30 \%$ showed a significant effect on the tested physical parameters and texture of snacks. The apparent density values for snacks varied from 101 to $187 \mathrm{~kg} \cdot \mathrm{m}^{-3}$ (Fig. 1). 
There was a visible effect ( $\mathrm{p}_{\text {-value }}=0.000$, Table 1 ) of the growing dragonhead bagasse addition on the positive correlation coefficient $\left(\mathrm{R}^{2}=0.741\right)$. The addition of 5 and $10 \%$ of dragonhead oilcake lowered apparent density of snacks. A further increase in the amount of bagasse addition, up to $30 \%$, resulted in a significant increase of the apparent density values, which could be the result of the increasing fiber, fat and protein content derived from dragonhead seeds oilcake waste.

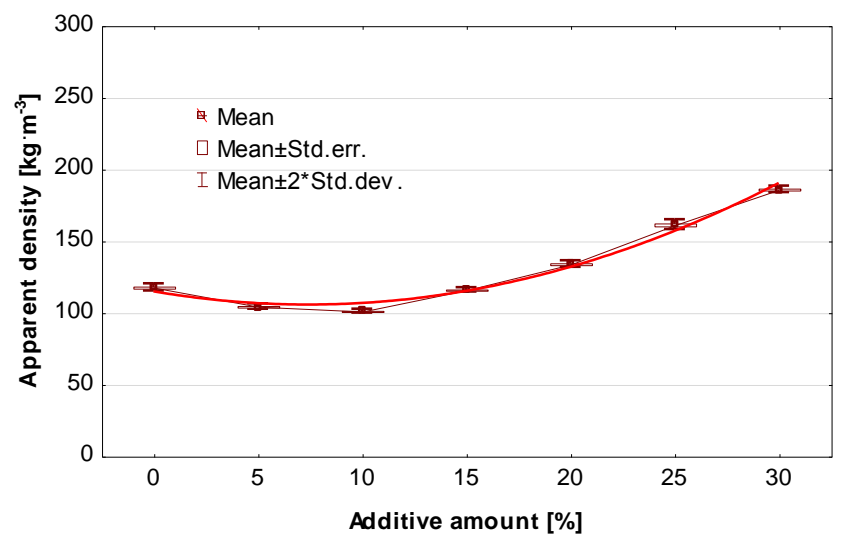

Fig. 1. Apparent density of extruded corn snacks with the addition of various amounts of dragonhead seeds bagasse waste

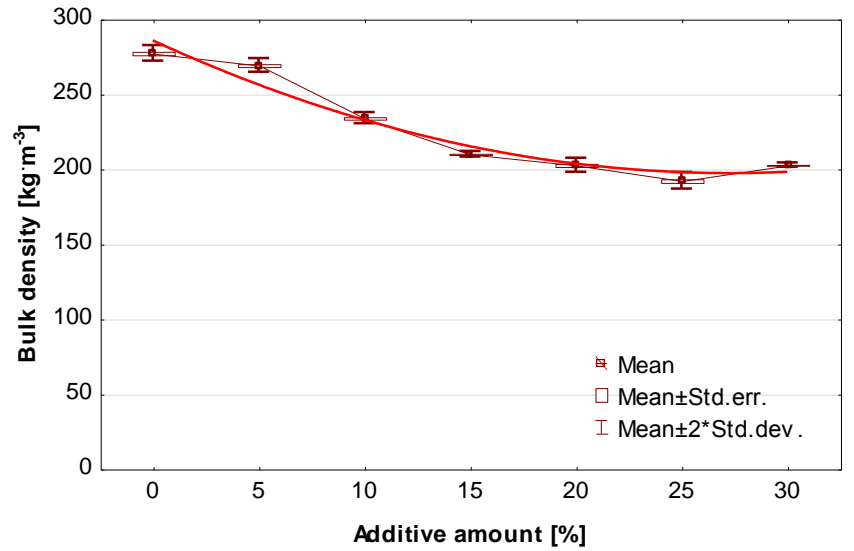

Fig. 2. Bulk density of extruded corn snacks with the addition of various amounts of dragonhead seed bagasse waste

Bulk density evaluated for corn snacks with the addition of Dracocephalum moldavica seed oilcake ranged from 188 to $271 \mathrm{~kg} \mathrm{~m}^{-3}$ (Fig. 2). These values were lower than those reported for corn snacks. The addition of bagasse makes snacks less compact and well puffed, thus significantly ( $\mathrm{p}_{\text {-value }}=0.000$, Table 1) limiting bulk density. For directly expanded snacks, this behavior is desirable, and low bulk density is usually connected with the high expansion and good crispness of snack products. Increased application of oilcake waste from dragonhead seeds lowered bulk density with $\mathrm{R}^{2}=0.846$.

The water absorption index of the extrudates is directly linked to the intensity of thermomechanical treatment during the extrusion-cooking process (Bouasla et al. 2017). The WAI of snacks based on corn and supplemented with the addition of dragonhead oilcake waste reached the values from 4.18 to $5.17 \mathrm{~g} \cdot \mathrm{g}^{-1}$. These values were similar or lower than in the case of corn snacks without any additives $\left(5.13 \mathrm{~g} \cdot \mathrm{g}^{-1}\right)$. A greater amount of bagasse waste lowered the water absorption of the tested snacks with $\mathrm{R}^{2}=0.699$ (Fig. 3). Ground oilcake, rich in fiber, protein and fat, added to corn grits is likely to disturb the 
DOI:

integration of components inside the extruder and reduce the processing intensity of ingredients. This effect was significant $\left(\mathrm{p}_{\text {-value }}=0.001\right)$ but the differences were limited (only $14 \%$ less than for corn snacks).

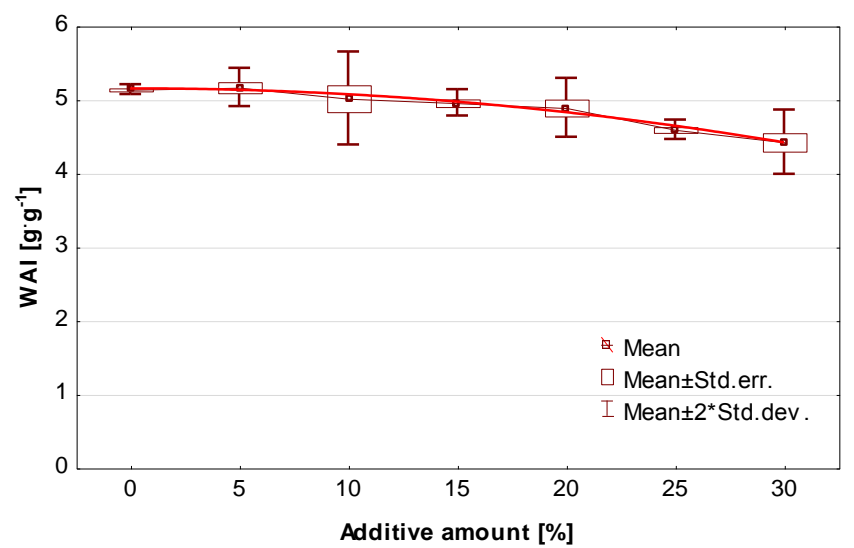

Fig. 3. The WAI of extruded corn snacks with the addition of various amounts of dragonhead seed bagasse waste

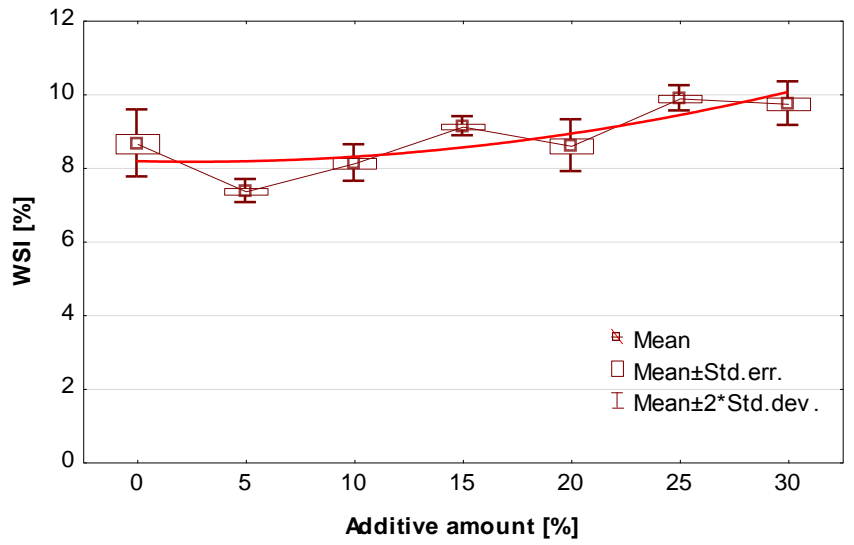

Fig. 4. The WSI of extruded corn snacks with the addition of various amounts of dragonhead seed bagasse waste

The results of the water solubility index of corn crisps supplemented with dragonhead seed bagasse waste ranged from 7.28 to $9.99 \%$ (Fig. 4). The differences between the means resulting from the supplementation were significant ( $\mathrm{p}_{\text {-value }}=0.000$, Table 1 ), but, as for the WAI, the WSI results were close: an increase of $37 \%$ was observed along with the growing amount of Dracocephalum moldavica seed bagasse waste in the recipe. The low values of water solubility reported for the tested extrudates showed a good integration of components during treatment and a low degradation of starchy components by thermomechanical treatment.

The cutting force measured for snacks supplemented with the Moldavian dragonhead ranged from $11.7 \mathrm{~N}$ for corn snacks to $15.4 \mathrm{~N}$ when $30 \%$ of the additive was used in the recipe (Fig. 5). A significant rise in the amount of the additive ( $\mathrm{p}_{\text {-value }}=0.00001$, Table 1 ) translated into greater hardness of the supplemented snacks, but even a high amount of the additive produced snacks with proper texture. Increased hardness (around 31\%) has no negative effect on the overall quality of the supplemented snacks. 


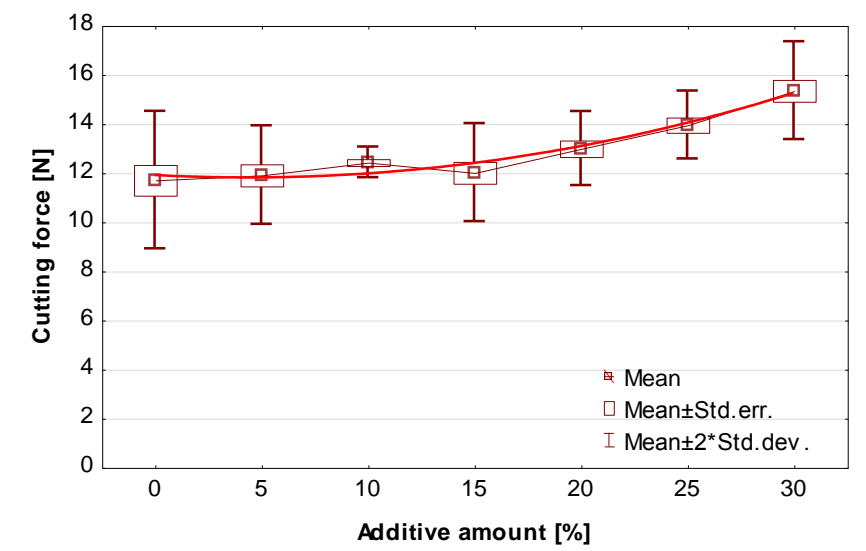

Fig. 5. The cutting force of extruded corn snacks with the addition of various amounts of dragonhead seed bagasse waste.

Table 1. A statistical analysis of the effect of dragonhead bagasse waste addition on the selected properties of extruded snacks

\begin{tabular}{|c|c|c|c|c|c|}
\hline Parameter & Polynomial quadratic equation & $\begin{array}{c}\text { F-test } \\
\text { value }\end{array}$ & p-value & $\begin{array}{c}\text { KW-H } \\
\text { test } \\
\text { value }\end{array}$ & p-value \\
\hline Apparent Density $\left(\mathrm{kg}^{-3}\right)$ & $\rho_{\mathrm{A}}=131.275-20.693 \mathrm{~A}+4.159 \mathrm{~A}^{2}$ & 2341.148 & 0.0000 & 19.498 & 0.0034 \\
\hline Bulk Density $\left(\mathrm{kg}^{-3}\right)$ & $\rho_{\mathrm{B}}=321.104-8.389 \mathrm{~A}+2.974 \mathrm{~A}^{2}$ & 1378.032 & 0.0000 & 32.747 & 0.00001 \\
\hline WAI $\left(\mathrm{g} \cdot \mathrm{g}^{-1}\right)$ & $\mathrm{WAI}=5.127+0.044 \mathrm{~A}-0.021 \mathrm{~A}^{2}$ & 7.459 & 0.0010 & 14.961 & 0.0206 \\
\hline WSI $(\%)$ & $\mathrm{WSI}=8.295-0.193 \mathrm{~A}+0.063 \mathrm{~A}^{2}$ & 30.048 & 0.0000 & 18.419 & 0.0053 \\
\hline Cutting Force $(\mathrm{N})$ & $\mathrm{F}_{\max }=12.261-0.489 \mathrm{~A}+0.131 \mathrm{~A}^{2}$ & 10.062 & 0.00001 & 22.051 & 0.0012 \\
\hline
\end{tabular}

A - additive amount; $\rho_{\mathrm{A}}-$ Apparent Density; $\rho_{\mathrm{B}}-$ Bulk Density; WAI - Water Absorption Index; WSI Water Solubility Index; $F_{\max }-$ Cutting Force

As reported by Wojtowicz et al. (2017), the addition of Dracocephalum moldavica leaves increased bulk density, cutting force and breaking index of enriched snacks products compared with corn snacks. It was linked to the lower expansion and porosity of extrudates with an addition of fibrous components and increased bulk density of products with a high ash and fiber level (Altan et al. 2008).

\section{CONCLUSIONS}

The application of Moldavian dragonhead seed oilcake as an additive was found to be suitable for the processing of corn crisps directly expanded in the extrusion-cooking process that yielded ready-to-eat snacks. The research proved a significant impact of the amount of additive on texture and the physical properties of the supplemented snacks. The use of dragonhead seed oilcake lowered bulk density and the WAI and increased apparent density, water solubility and hardness of the tested snacks. The discussed results demonstrate a possibility of the application of dragonhead seed bagasse waste as a functional additive to corn snacks without any negative effect on the quality of extrudates. This makes the extrusion-cooking technique suitable for the sustainable management of waste products that offer an improved nutritional composition compared with conventional corn snacks.

\section{REFERENCES}

Altan, A., McCarthy, K., \& Maskan, M. (2008). Evaluation of snack foods from barley-tomato pomace blends by extrusion processing. Journal of Food Engineering, 84, 231-242. 
DOI:

Aprotosoaie, A.C., Mihai, C.T., Vochita, G., Rotinberg, P., Trifan, A., Luca, S.V., Petreus, T., Gille, E., \& Mirona, A. (2016). Antigenotoxic and antioxidant activities of a polyphenolic extract from European Dracocephalum moldavica L. Industrial Crops and Products, 79, 248-257.

Bouasla, A., Wójtowicz, A., Zidoune, M.N., Olech, M., Nowak, R., Mitrus, M., \& Oniszczuk, A. (2016). Gluten-free precooked rice-yellow pea pasta: effect of extrusion-cooking conditions on phenolic acids composition, selected properties and microstructure. Journal of Food Science, 81(5), C1070-1079.

Bouasla, A., Wójtowicz, A. \& Zidoune, M. (2017). Gluten-free precooked rice pasta enriched with legumes flours: Physical properties, texture, sensory attributes and microstructure. LWT-Food Science and Technology, 75, 569-77.

Dastmalchi, K., Dorman, D.H.J., Laakso, I., \& Hiltunen, R. (2007). Chemical composition and antioxidative activity of Moldavian balm (Dracocephalum moldavica L.) extracts. LWT-Food Science and Technology, 40(9), 1655-1663.

Domokos, J., Peredi, J., \& Halaszzelnik, K. (1994). Characterization of seed oils of dragonhead (Dracocephalum moldavica L.) and catnip (Nepeta cataria var. citriodora Balb.). Industrial Crops and Products, 3, 91-94.

Dziki, D., Miś, A., Gładyszewska, B., Laskowski, J., Kwiatkowski, S., \& Gawlik-Dziki, U. (2013). Physicochemical and grinding characteristics of dragonhead seeds. International Agrophysics, 27, 403-408

Gagoś, M., Matwijczuk, A., Kamiński, D., Niewiadomy, A., Kowalski, R.,\& Karwasz, G.P. (2011) Spectroscopic studies of intramolecular proton transfer in-(4-Fluorophenylamino)-5(2,4-Dihydroxybenzeno)-1,3,4-Thiadiazole. Journal of Fluorescence, 21(1), 1-10.

Hanczakowski, P., Szymczyk, B., Kwiatkowski, S., \& Wolski, T. (2009). Skład i wartość pokarmowa białka nasion pszczelnika mołdawskiego (Dracocephalum moldavica L.). Roczniki Naukowe Zootechniki, 36(1), $55-61$.

Jiang, J., Yuan, X., Wang, T., Chen, H., Zhao, H., Yan, X., Wang, Z., Sun, X., \& Zheng, Q. (2014). Antioxidative and cardioprotective effects of total flavonoids extracted from Dracocephalum moldavica L. against acute ischemia/reperfusion-induced myocardial injury in isolated rat heart. Cardiovascular Toxicology, 14, 74-82.

Kręcisz M., \& Wójtowicz A., (2017). Evaluation of selected properties of gluten-free instant gruels processed under various extrusion-cooking conditions. Acta Scientiarum Polonorum, Technologia Alimentaria, 16 (2), 135-147.

Oniszczuk, A., Wójtowicz, A., Oniszczuk, T., Olech, M., Nowak, R., Wojtunik, K., Klimek, M., Krawczyk, W., \& Waksmundzka-Hajnos, M. (2015). Extruded corn gruels containing linden flowers: quantitation of phenolic compounds and selected quality characteristics. Open Chemistry, 13, 1209-1217.

Yang, L.-N., Xing, J.-G., He, C.-H., \& Wu, T. (2014). The phenolic compounds from Dracocephalum moldavica L. Biochemical Systematics and Ecology, 54, 19-22.

Wójtowicz, A., Mitrus, M., Oniszczuk T., Mościcki L., Kręcisz, M., \& Oniszczuk A. (2015). Selected physical properties, texture and sensory characteristics of extruded breakfast cereals based on wholegrain wheat flour. Agriculture and Agricultural Science Procedia, 7, 301-308.

Wójtowicz A., Oniszczuk A., Oniszczuk T., Kocira S., Wojtunik K., Mitrus M., Kocira A., Widelski J., \& Skalicka-Woźniak K. (2017). Application of Moldavian dragonhead (Dracocephalum moldavica L.) leaves addition as a functional component of nutritionally valuable corn snacks. Journal of Food Science and Technology. DOI :10.1007/s13197-017-2765-7. 